\title{
Lip and Oral Cavity Cancer pT2 TNM Finding v6 and v7
}

National Cancer Institute

\section{Source}

National Cancer Institute. Lip and Oral Cavity Cancer pT 2 TNM Finding v6 and v7. NCI

Thesaurus. Code C64412.

Lip and oral cavity cancer with tumor size more than 2 centimeters, but not more than 4 centimeters in greatest dimension. (from AJCC 6th and 7th Eds.) 